\title{
Three Drawings for Three Stories about Portuguese Cultural Heritage
}

\author{
Fátima Pombo, University of Aveiro* \\ Sónia Teles e Silva
}

\begin{abstract}
This article aims to discuss the specificity of three author's projects to elaborate about the partnership between traditional economic sectors and design as added value regarding cultural heritage as framework for sustainable solutions. The scenery of intervention is the refurbishment of a single-family home that motivated the creation of three types of products: an entrance door, an armed chair with a footstool and eight carpets. The three projects started from hand drawings of one of the architects of the architecture office in charge of the assignment. In this text it is considered the concept of home and surrounding objects from an organic, human centred perspective, recalling, among others, essays as Bauen Wohnen Denken from Martin Heidegger and Rationalism and Man from Alvar Aalto as key texts that give the note of this text's approach. The analysis goes further by addressing the product's development process through the immersive collaboration of the architects with the client, technicians, workers of the chosen factories, namely metalwork, carpentry/carving and hand knotting. Finally, in this article it is to remark that these projects are a significant example to illustrate the partnership that can be experienced between arts \& crafts production and design proposals. In effect, the craft industry that remains in the market with competitive parameters is the one that adapts techniques and skills of the tradition and innovates in concepts.
\end{abstract}

Keywords: home, product design, drawing, arts \&crafts 


\section{Introduction}

The three stories that this article addresses start from the need to give a solution to three demands related with the refurbishment of a single-family house in multiple scales till the level of potentially becoming a home through the client's inhabitation. In this text the analysis falls on the design of an entrance door, eight carpets and an armchair with a footstool. The responses put in motion an architecture office ${ }^{1}$ and three types of crafts: metalwork, carpentry/carving and hand knotting. It was also paramount that the three pieces were original and reflect the skills of Portuguese arts \& crafts. Therefore, the three projects mirror the approach of design to the traditional knowledge of those activities, whether more technical or more handmade, acquiring an identity that allies tradition and contemporaneity. Home was perceived by the architecture office as a human-centric design scale offering interiors with comfort, coziness, warmth and quality. At the same time, the home should be in harmony with the surrounding landscape and to point out to nature as inspiration to life. Finally, design decisions intended that the products display a feeling for sustainable awareness from the concept till the final outcome. The house even if tuned with the language of the functionalism, rationalism and efficiency, unveiled an interior's ambience that resonates creativity to shape spaces for enjoying home. Therefore, instead of furnishing it with readymade sets of furniture, the choice was rather to design furniture and carpets to unfold a warm, familiar and comfortable atmosphere. And if the chair is probably the most designed piece of all times and in a way is the symbol of the ability to design a product to be used and enjoyed by the individual, this time the challenge was to design an armchair paired with a footstool. The carpets were designed according to room's functions and ambiences and were spread at home, giving immediately a strong expression of quietness and well-being. The door is a very demanding piece of design, providing a delineation between what belongs to the outside space and to the inside space. Moreover, this door 
should open to a large entrance hall that is the first open space to welcome guests. The following stories showcase the successful intertwining of a set of actions that ended up in three types of exclusive products that expose cultural heritage as a paramount parameter to design along. The factories were chosen in order to respond to the demand. The collaboration between the factories' responsible, workers, client and architects was very fruitful. Very often the architects were immersed in the factories pouring an exchange of knowledge and skills. Other possibilities of combination of design as added value within the scope of patrimonial validation were foreseen for future projects.

This article adopts a structure based upon two chapters namely the chapter Home and Surrounding Objects and the chapter Three Projects for a Single-family Home. In Home and Surrounding Objects the concept of home is analysed by recalling the ideas of three known authors as Witold Rybcznski, Martin Heidegger and Alvar Aalto who, from different background, contribute to elaborate about home in the sense that the architecture office mentioned responded to the assignment in discussion. In Three Projects for a Singlefamily Home three designed products are interpreted starting from the hand drawing in which every product is originated and then, placing them in the productive process within the Portuguese traditional crafts and techniques framework. This article addresses cultural heritage as an approach to reinforce sustainable design solutions.

\section{Home and Surrounding Objects}

Home is ideally the space associated with the most private and intimate space. It is a place with a strong symbolic, affective and emotional essence and therefore it is much more than a functional scenery. Witold Rybczynski writes an appealing book about the idea of home arguing that it is an attempt to discover (...) the meaning of comfort.' ${ }^{2}$ And he confessed that it was only 
when my wife and I built our own home that I discovered at first hand the fundamental poverty of modern architectural ideas. I found myself turning again and again to memories of older houses, and older rooms, and trying to understand what had made them feel so right, so comfortable.'3 This statement recalls the essay Building Dwelling Thinking from Martin Heidegger ${ }^{4}$ in which he debates the action of dwelling and building not 'as an art or as a technique of construction; rather [tracing] building back into that domain to which everything that is belongs. [So] We ask: 1.What is it to dwell? 2. How does building belong to dwelling?'5 For Heidegger, the quality of dwelling questions the quality of building. To build should respond to the needs of the human being (Da-sein) to dwell with quality, once dwelling is essential to live. Dwelling is, then to Heidegger, to join earth, heaven, mankind and spirituality (the divine). In Bauen Wohnen Denken, the philosopher develops a discourse around the etymological roots of the word 'build' (bauen) reflecting on its connection and impact in the act of dwelling (wohnen). 'Only if we are capable of dwelling, only then can we build. (...) 'Dwelling, however, is the basic character of Being in keeping with which mortals exist. (...) Building and thinking are, each in its own way, inescapable for dwelling. The two however, are also, insufficient for dwelling so long as each busies itself with its own affairs in separation instead of listening to one another.' ${ }^{6}$ Heidegger since 1922 inhabited frequently a modest, simple house during five decades as an occasional shelter from the busy life of the city where he lived and from the demanding academic life in Freiburg. He called it the hut. There, he stayed many times alone to think and to write. It was built in the Black Forest (Schwarzwald) close to the Todtnauberg village in the vicinity of Freiburg. 'The building surveys the landscape, sheltered and framed by trees. (...) The hut measures approximately six meters by seven. It is made largely of timber, framed and clad with timber shingels. (...) The hut's external walls are painted gray. Windows, doors, and shutters are painted in bright colors. 
(...) Window transoms, mullions, and casements are a brilliant white. Their frames are canary yellow and architraves a deep blue. Hinged shutters are painted leaf green. The door is also green with a blue frame. ${ }^{7}$ The dwelling of the hut enhances the bond of Heidegger with the landscape and there he philosophically thought and wrote about concepts as inhabiting, the sense of place, the sense of Being and Time (Sein und Zeit).

The condition of dwelling emphasizes the importance to think about the domestic space, its design and the surrounding objects which challenges the process of transforming the space utilitarian relationship into an existential relationship with meaning and value. Aligned with this thought, it is worth to recall the lecture of Alvar Aalto Rationalism and Man written in 1935 in which he distanced himself from the functionalist ideology, stating that 'objects that can rightly be called rational often suffer from flagrant inhumanity' and that 'formalism is inhuman to the highest degree.' ${ }^{\prime}$ Aalto as his wife, the architect and designer Aino Marsio-Aalto, were critical of the white textures, the cold surfaces of steel and glass, of the geometry of the forms, of the hygienic purity of the minimalism and, above all, of the techno-rational and ahistorical refusal of spaces and objects. They argued and practiced the combination of realism and imagination, rational and intuition, the proximity of nature, the integration of the vernacular, the aesthetical pleasure of the senses, and not to lose the soul. Peter Zumthor, in other terms, defends the same as Alvar and Marsio Aalto regarding architecture: 'The magic of the real: that to me is the 'alchemy' of transforming real substances into human sensations, of creating that special moment when matter, the substance and form of architectural space, can truly be emotionally appropriated or assimilated.' ${ }^{\prime 9}$ And he adds: 'I try to make sure that the materials are attuned to each other, that they radiate; I take a certain amount of oak and a different amount of pietra serena and add something to them: three grams of silver or a handle that turns or maybe surfaces of gleaming glass, so that every combination of materials yields 
a unique composition, becomes an original. (...) I give thought to careful and conscious staging of tension between inside and outside, public and intimate, and to thresholds, transitions, and borders.' ${ }^{10}$ This interest and attention regarding perceptive features and atmospheric qualities of the spaces are framed by the phenomenology of architecture and design practice. ${ }^{11}$ There are, then, designed objects that besides accomplishing their useful function, express features that promote an authentic relationship of longevity between the individuals and objects, integrated in contexts and experiences that are day-to-day meaningful. The following projects aim to represent such purpose.

\section{Three Projects for a Single-family Home}

\section{From Camellias to a Carved Armchair}

Porto is known for the strong attachment to camellias. Brought from the Orient by Jesuit missionaries, it is in the first half of the $19^{\text {th }}$ century that camellias conquer Porto's gardens. José Marques Loureiro (1830-1898), the Gardner of Virtudes, ${ }^{12}$ by cultivating a splendorous garden, at the time called Horto das Virtudes in the historical town's core, contributed to transform Porto in the camellias town. Still nowadays Porto hosts an extensive exhibition of camellias and activities around the flower during a few days each March. As if the exhibition celebrates in advance the coming of springtime. Among the numerous species of this flower there is one that blossoming in March received the name of 'Cidade do Porto'. From here camellias reached all the north of Portugal and Galiza in Spain. The sun in Porto does not damage these flowers, because the humidity from the Atlantic acts like a filter. It is not such a surprise that the park close to the house to which the armchair and the footstool were designed for has promenades and corners full of camellias. ${ }^{13}$ Sónia ${ }^{14}$ has been captivated for a long time by these flowers and has drawn dozens of it with all sizes and colours. It was from some of those drawings that the pattern for the carved armchair was inspired. (Fig. 1) 


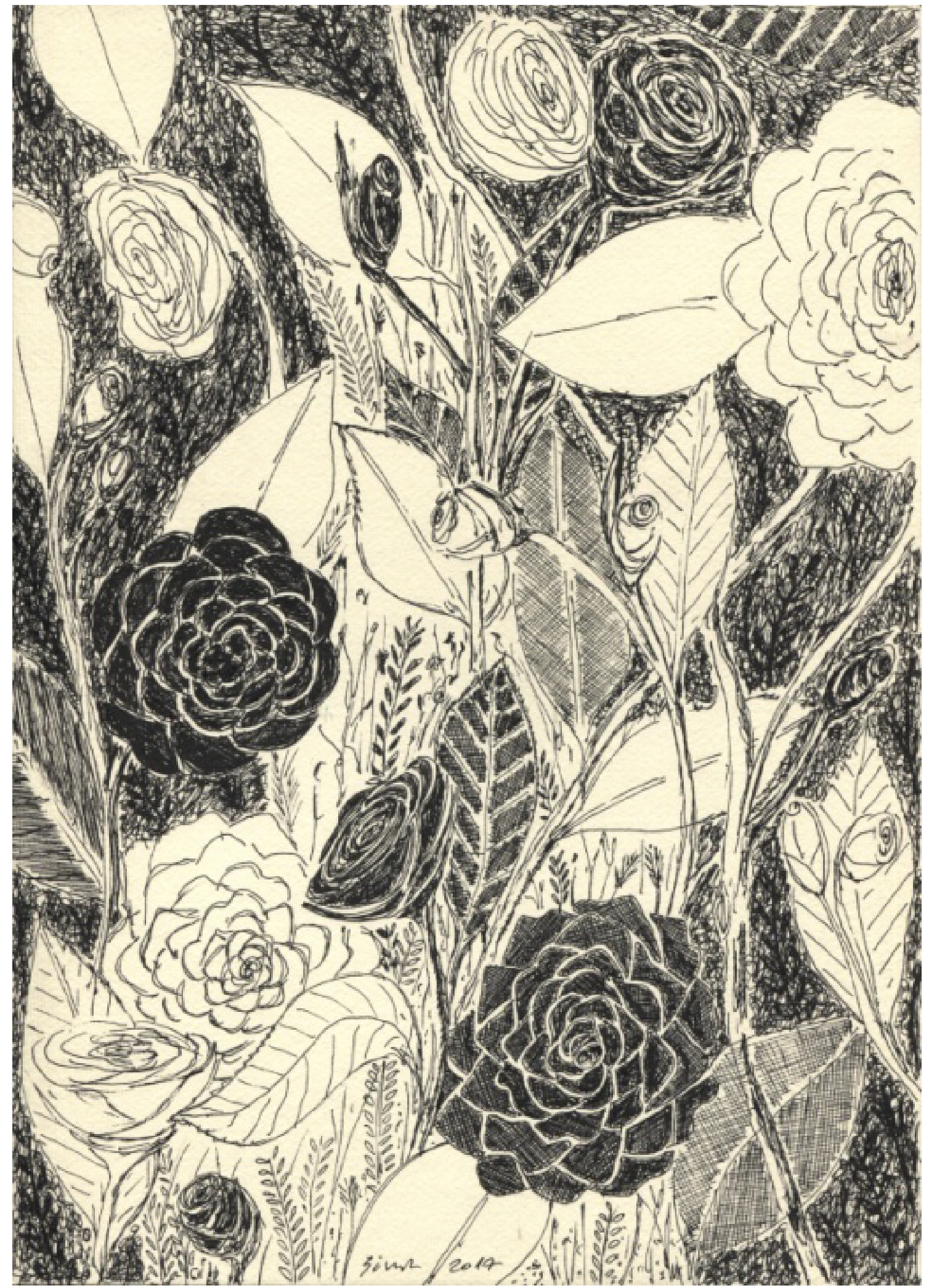

Fig. 1: Camellias in china ink. C Sónia Teles e Silva 
It was decided, then, to design and build a wooden armchair and a footstool integrating the very Portuguese wood carving art. In effect, carpentry, cabinet making, wood carving and upholstery were called to work in a close dialogue with client and architects. The camellias drawing was directly hand drawn by Sónia in the wood piece in the exact scale to be carved. (Fig. 2)

Figure 3 shows the woodcarver artist ${ }^{15}$ working on the back of the armchair and the rigorous drawing that was also made by the architects. The direct contact of the architects with the woodcarver was paramount to bring the camellias drawing into the final version. During the meticulous process of building it the architects got also acquaintance with terms, tools, utensils, techniques that were used in this craft.

Portugal has a remarkably rich and long tradition in the work of wood furniture and related wood artefacts, notable both in concept and form and in techniques and production processes. This tradition is in risk of disappearing due to several reasons, namely the response to ephemeral market tendencies based upon the reproduction of trends that follow passing and phlegmatic demands. The production of this armchair and footstool showed the opportunity to integrate design with the use of traditional crafts and techniques. The armchair's drawing was adjusted in order to accommodate the necessary technology, namely adapting the oblong form to the CNC cutting machine and the element hand carved by a carver artist. Some studies were tested once the carved wood in the back raised some technical challenges to cabinet making and to upholstery. The solution for the product's final form is to be seen in Figure 4 that displays the front and back in natural leather upholstery with a curved element in brown wood firstly cut by the CNC machine and then hand carved. 


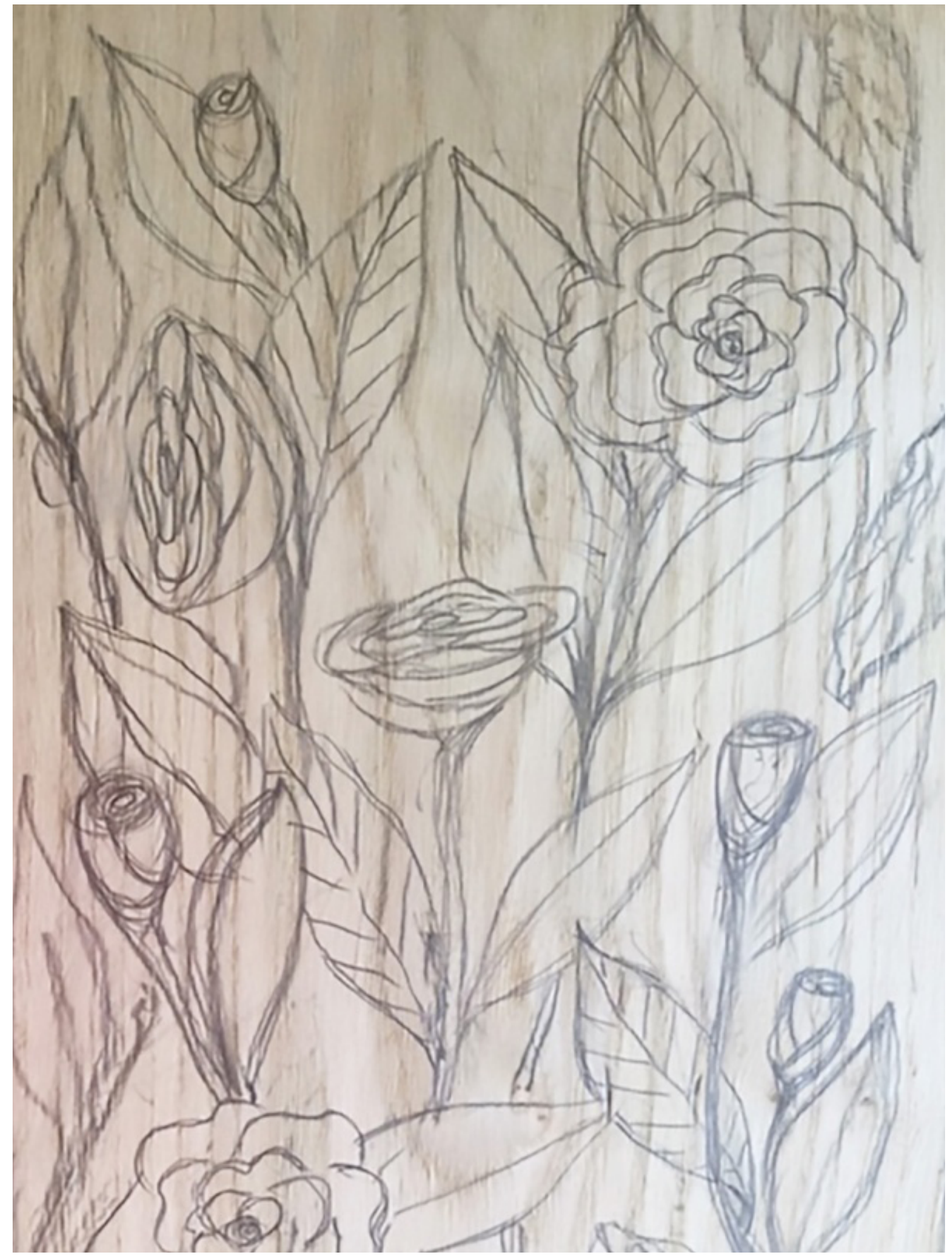

Fig. 2: Graphite drawing in brown wood in full-scale (C) Sónia Teles e Silva 


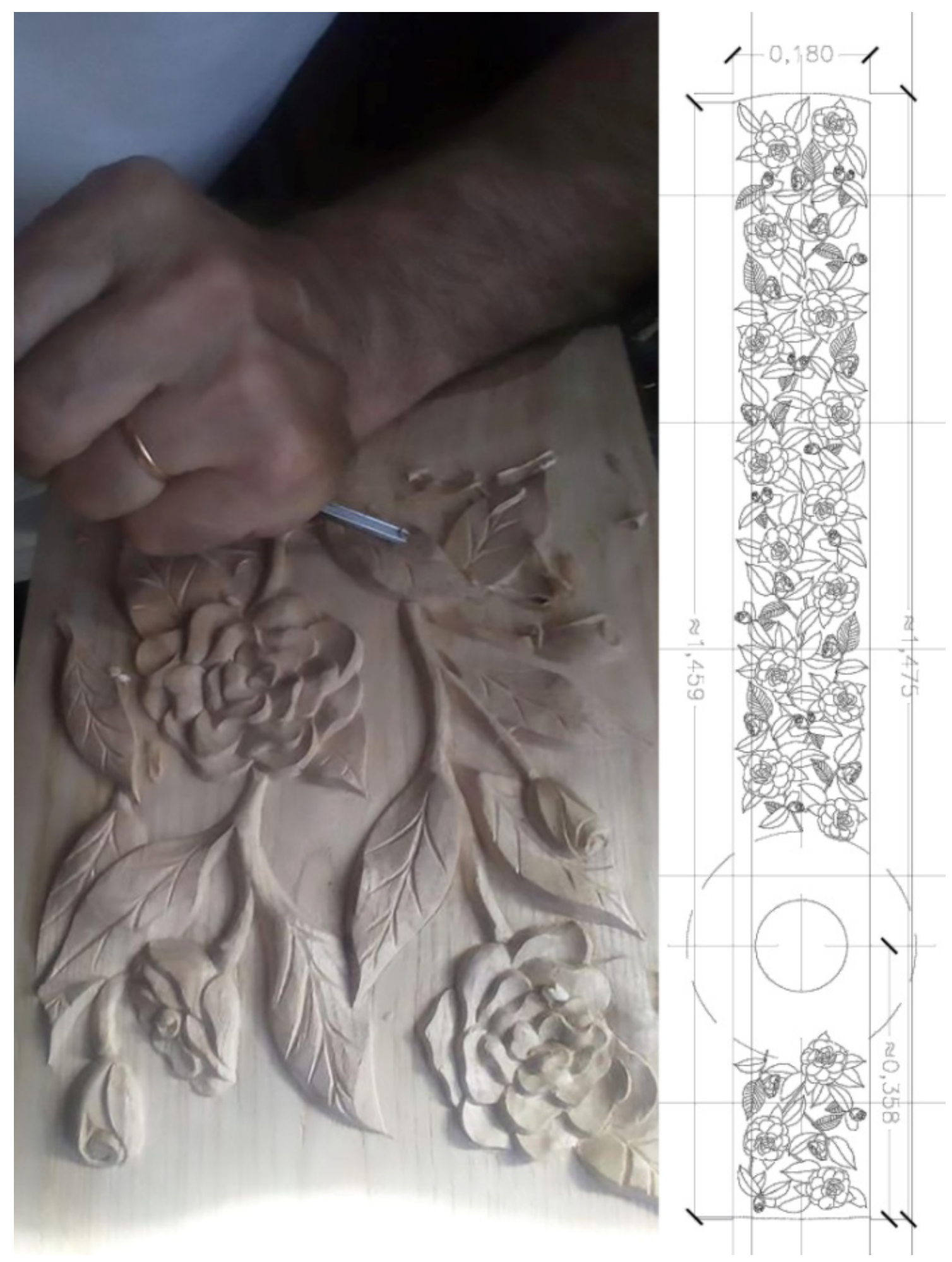

Fig. 3: António Carneiro, woodcarver. Rigorous drawing of the camellias by SJGS Arquitectos. (C) SJGS Arquitectos 


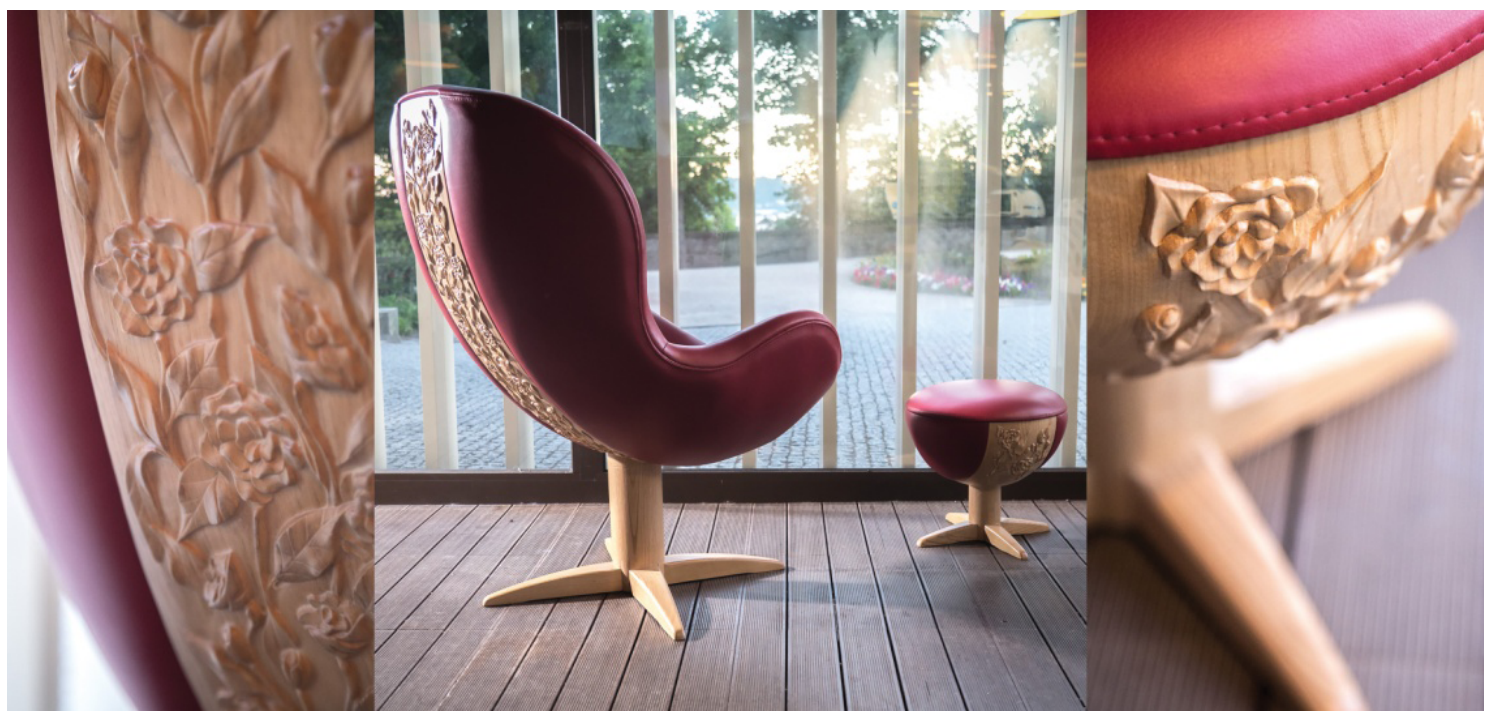

Fig. 4: Armchair and footstool (C) Nuno Pereira

The armchair named by the client Cadeirão Tempo and the footstool were displayed in The Best Furniture in the World exhibition in Torre dos Clérigos do Porto. ${ }^{16}$

\section{From Algae to Carpets}

The long coastal zone of the country and the closeness of the sea in the city of Porto enhance the water as inspiration for many maritime activities, as it is catching algae to create an Algae Book.

Sónia is composing an Algae Book for some years, a skill and interest she inherited from her grandfather who gathered an exquisite collection of algae that he donated to the Maritime Museum of Ilhavo ${ }^{17}$ as well as wrote a book about preparing and conserving algae. ${ }^{18}$ In effect, it was from Guia Prático de Preparação de Algas Marinhas and from the Algae Book that emerged the algae patterns transposed to the carpets. It was necessary to provide eight carpets that should have the same leitmotiv but expressing diversity according to the place they were meant for. Eight algae were chosen by the client together with the architects (Fig. 5) for eight different carpets for eight different rooms to be made in a traditional Portuguese familiar factory specialized in carpets known as 'tapete de Beiriz'. 


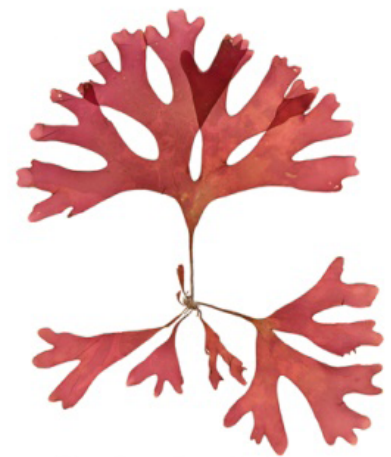

Chondrus crispus Stackhouse

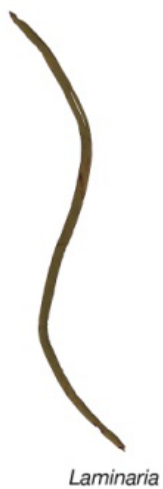

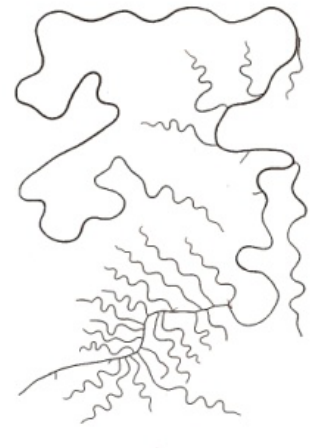

Dumontia sp.

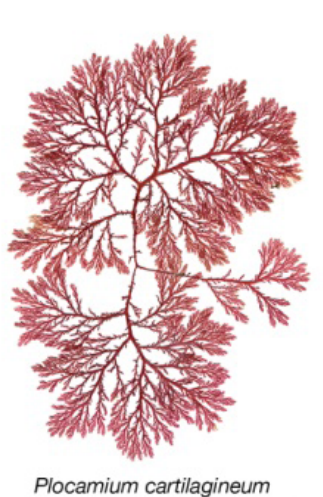

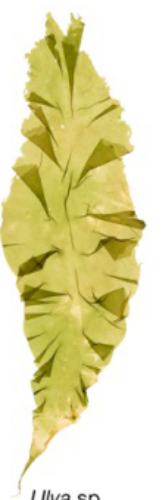

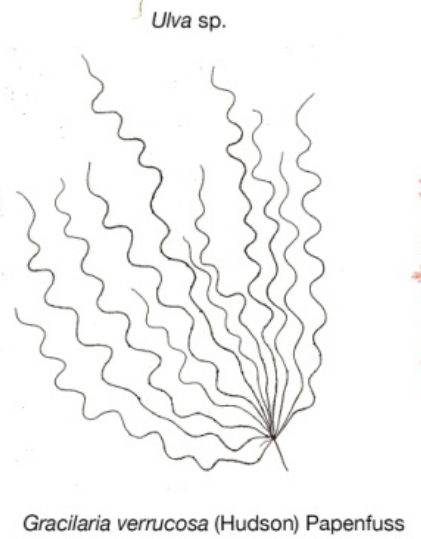

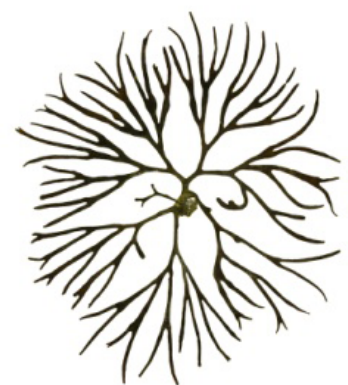

Codium Stackh

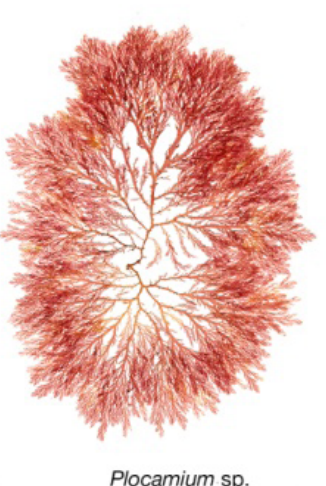

Fig. 5: Eight algae for eight carpets ${ }^{22}$ C Leonor Secca

Tapete de Beiriz is a handcraft carpet in wool originating from Beiriz, a locality that belongs to Póvoa de Varzim in the district of Porto, in Portugal. The first Beiriz carpet's factory was founded in 1919 by Hilda Brandão, a Portuguese aristocrat living in Beiriz. She started with six artisans and two looms. In 1934 the factory had 350 artisans and sixty looms which reveals the success of these carpets. In effect, they conquered national and international taste by quality, beauty and originality, consolidating their position in the market till the factory closed its doors in the 1970s. However, in 1988, a German businesswoman bought several of the old looms, recruited some of the former workers and reopened a factory in Beiriz using the same techniques to hand knot carpets with the prestige of the old times. The particular characteristic of the carpets is defined by a kind of knot called 'ponto de Beiriz'. Each piece, made of $100 \%$ wool, is hand knotted on a loom by several women in line with synchronic movements, involving an extremely thorough work that asks for great expertise. Figure 6 shows the artisans working on one of the carpets. 
This technique allows the possibility to work with detailed drawings and to make very resistant and durable carpets. Almost 100 years after carpets were woven in Beiriz, these 'algae carpets' were hand knotted in the same traditional way. ${ }^{19}$ The drawing from the algae was adapted to the carpets dimensions, each one with a different colour to be involved in the room's atmosphere. Figure 7 presents the carpet in the dining room.

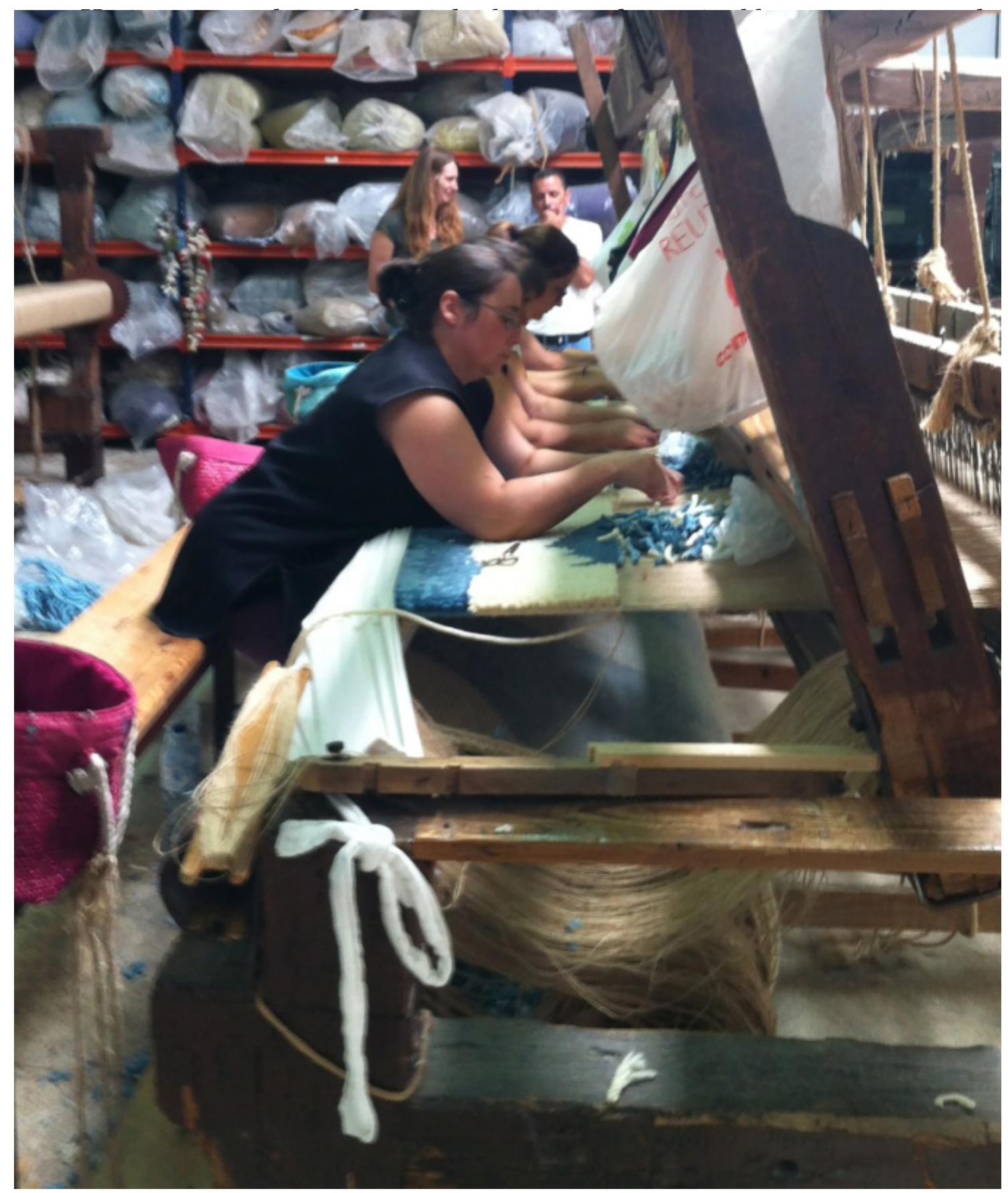

Fig. 6: Artisans hand knotting the blue carpet in a loom (C) SJGS Arquitectos 
Graphic simulations of the space with the carpets were experimented and rigorous drawings from the carpets were done till the desired composition was achieved. Later, in the factory the drawings were adjusted to the matched technique with the choice of the knots' density and the selection of the wool colours' palette. The result was eight carpets, all different and exclusive to integrate a 'total work of art' planned to resonate the atmosphere to dwell in.

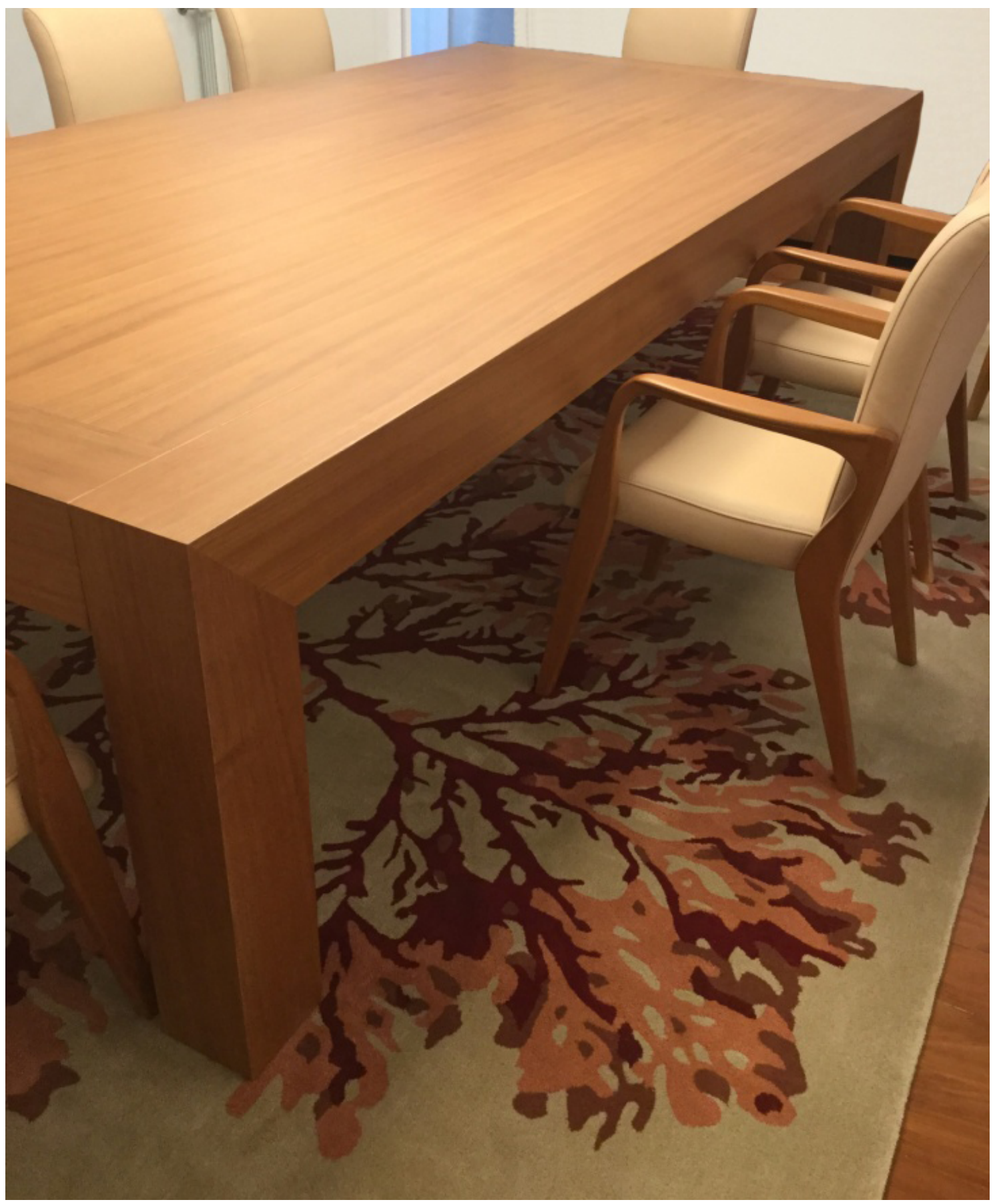

Fig. 7: The carpet for the dining room. C SJGS Arquitectos 


\section{From the Ginkgo biloba leaf to an entrance door}

Ginkgo biloba trees can also be found in various areas in Porto. The most beautiful bicentennial female specimen with $35 \mathrm{~m}$ high can be found in the Garden of Virtues that was already referred in this article. ${ }^{20}$ There are many Ginkgo biloba trees in the park close to the house that has an entrance door with multiple leaves of Ginkgo biloba made in steel plate. Besides the good quality and lightness of its wood, this tree is known for ornamental reasons and, above all arguments, for its medicinal properties. This fame is originated in ancestral times, since in China it was used to increase the organism resistance to several diseases. And that glory remains nowadays as it is considered a healthy element that benefits the balance of the body and the mind. Sónia has been drawing many Ginkgo biloba leaves from the trees of that park. The drawing of one of that leaves, was chosen to be the pattern of the entrance door. (Fig. 8)

The door is a space as an edge that is used daily. It delimits the inside and the outside. Symbolically the leaves of this tree establish the connection with the landscape, namely referring to the many Ginkgo biloba trees from the park. The factory that produced the door has the motto 'iron work artistry'21 and develops a conceptual work in urban window frames, going beyond technical skills by investing in research and innovation. From the drawing of the Ginkgo biloba leaves other technically rigorous drawings from the door as well as models of the cut steel plate were experimented till the final integrative solution. Figure 9 provides a moment of those experiments.

The direct contact in the factory with all team involved, namely architects, workers, technicians and client was decisive to adapt the product's concept with technical performance and materials. The factory was able to develop from a strong creative and demanding stage a single product, through the blending of a technological standard performance with a more craft oriented solution. The 
main door from the house is large, light and very safe. The translucent double glass with the overlapped ginkgo leaves repeated pattern in steel, filter the light and ensure privacy as Figure 10 demonstrates.

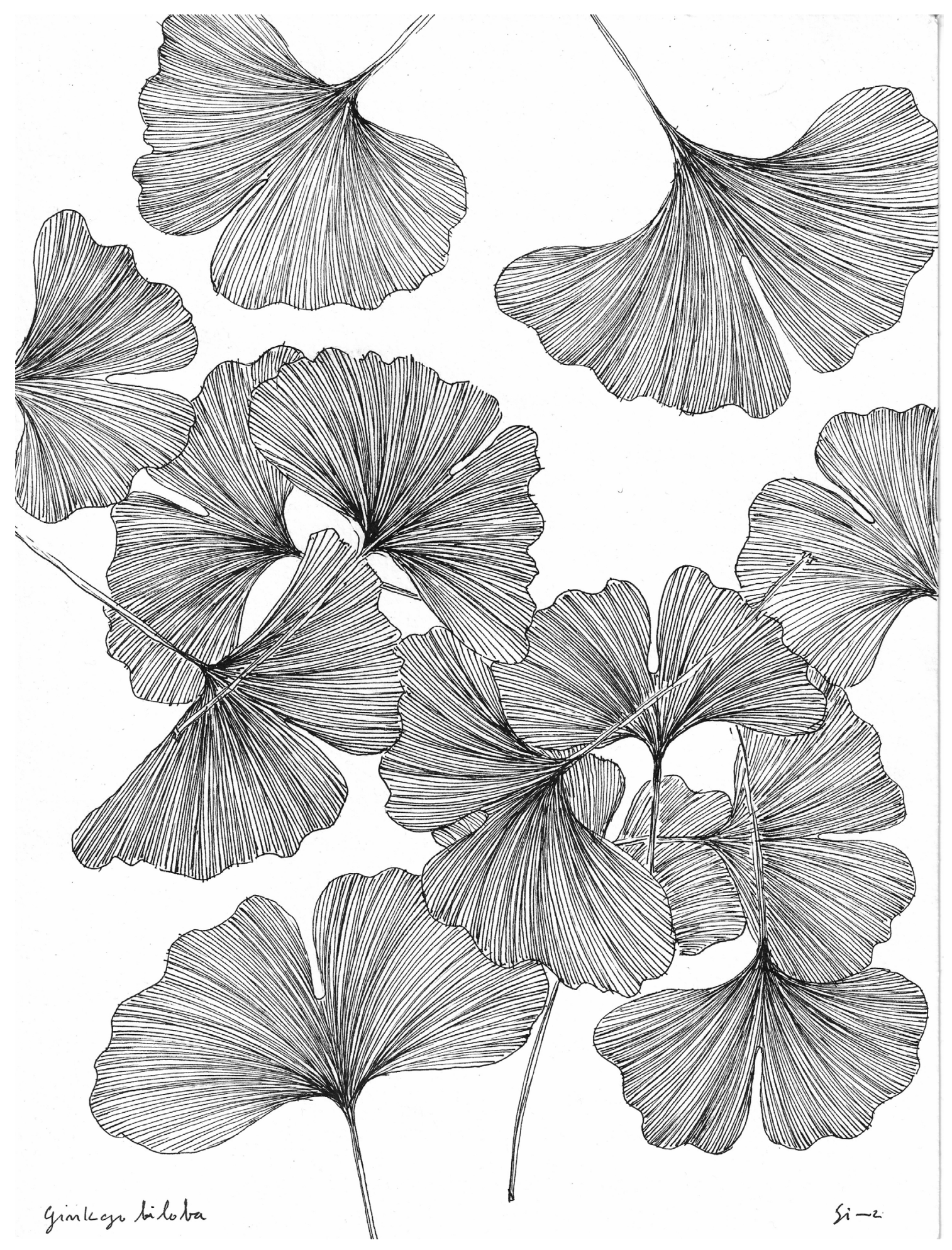

Fig. 8: Ginkgo biloba in china ink. (C) Sónia Teles e Silva 


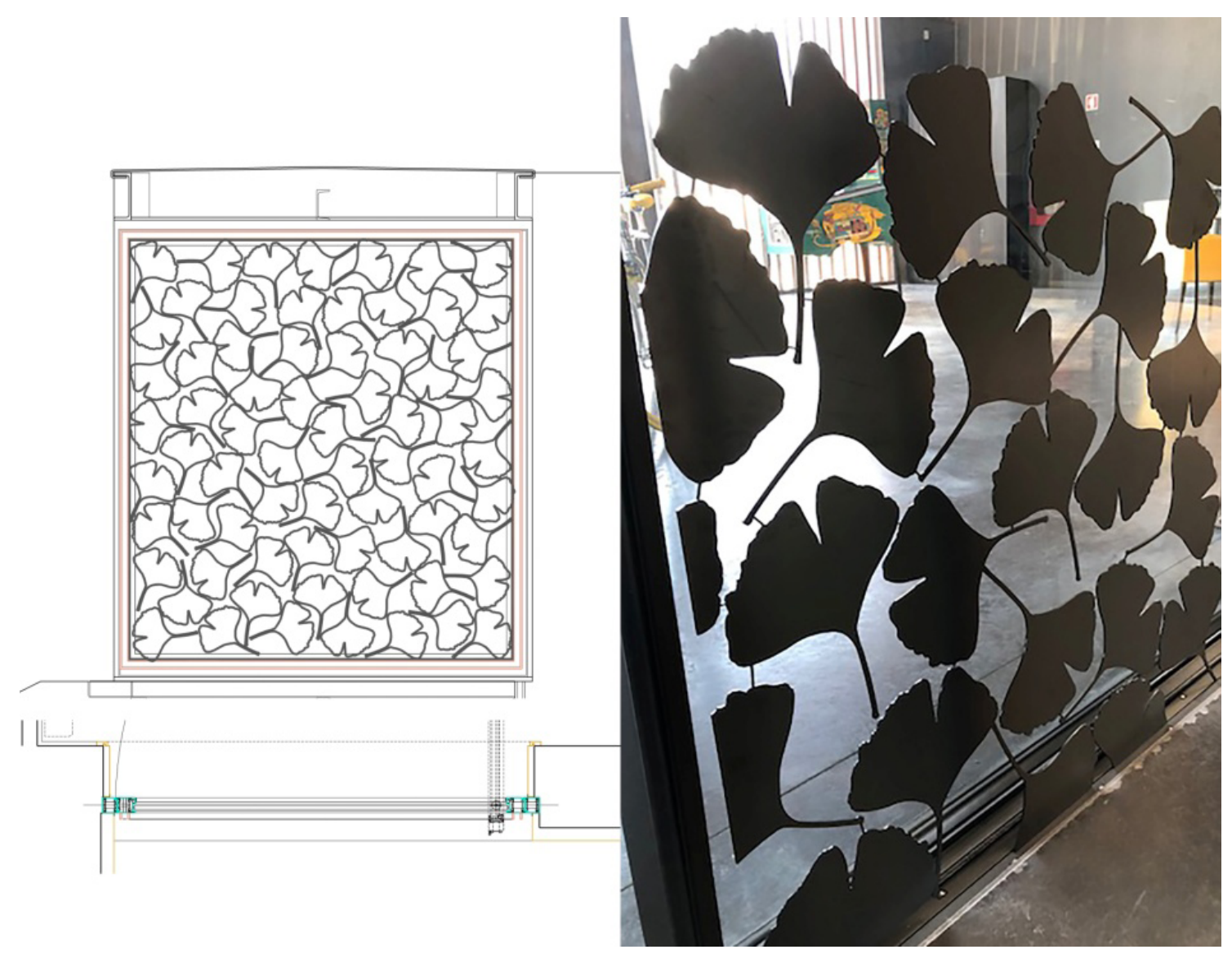

Fig. 9: Entrance door's rigorous drawing by SJGS Arquitectos and experiment in steel plate (C) SJGS Arquitectos

\section{Final Remarks}

A general refurbishment of a single-family house in different design scales included the design of products in order to create the wished atmosphere to dwell. The above mentioned projects are a valuable example to illustrate the successful partnership that can be experienced between the arts \&crafts production and design proposals with the proximity of all stakeholders cooperating. The craft industry that remains in the market with competitive parameters is the one that was able to adapt techniques and skill of the tradition and innovate in concepts. In parallel some craft industries introduced the modernization of equipments as a way of adapting to the market with a more competitive and versatile manufacturing. The production of low technology may reinforce the genesis of a product genuinely Portuguese as well as reinforce the goals of sustainability. 


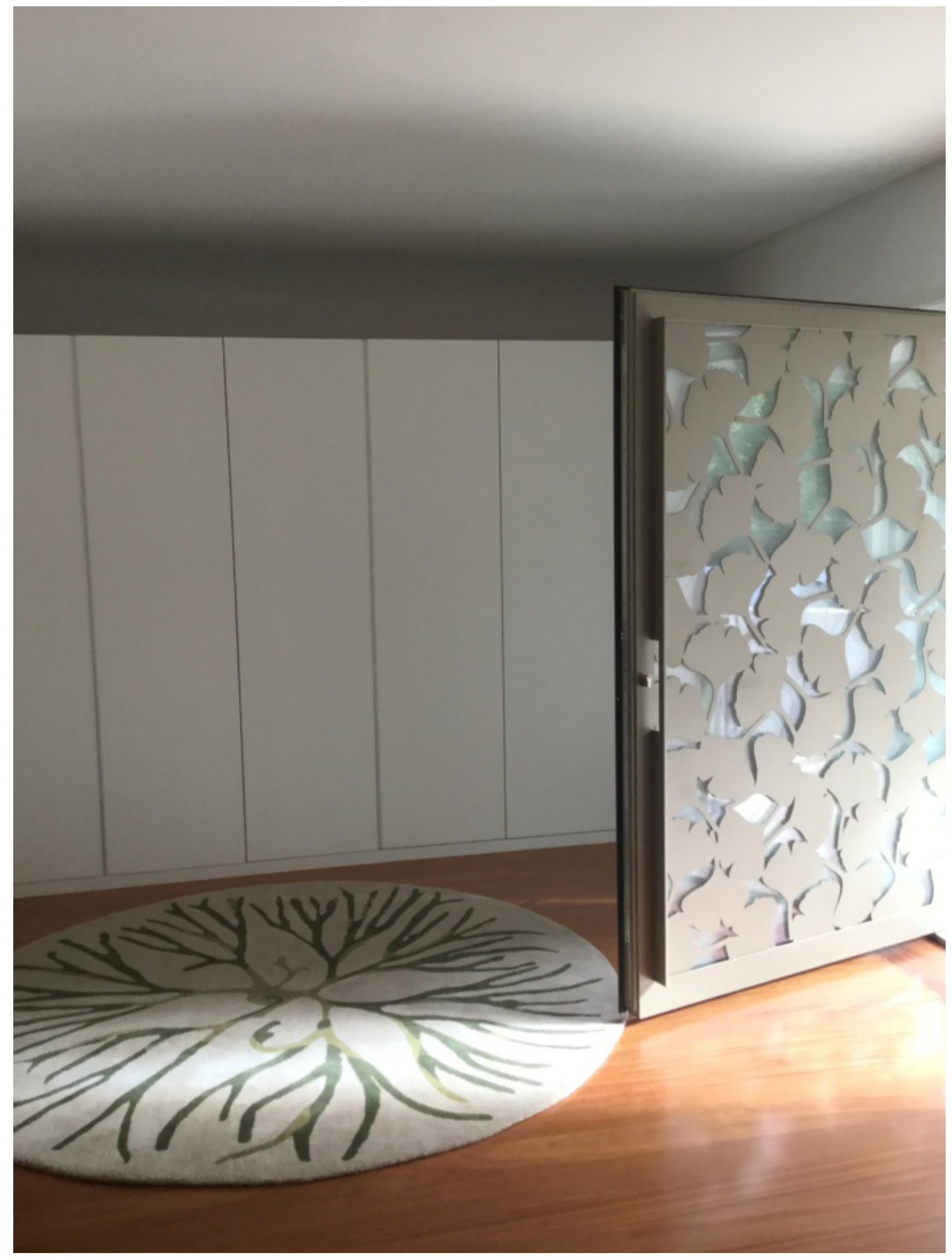

Fig. 10: Entrance door Ginkgo biloba. (C) SJGS Arquitectos 
The three examples abovementioned show a very clear interpretation of the nature of the form, the physical and mechanical characteristics of the raw material and the knowledge of traditional techniques, tools and skills. The close interaction of the architects with the craft workers stimulated the argument of the rapprochement of the crafts through the design mediation. Design, cultural heritage, economic production should work together towards a more resilient future. Contemporary societies urge for an ethical attitude towards the planet with and environmental consciousness and responsibility in the consumerism that points out to the need of educating more critical and demanding consumers matching more sustainable ways of living. Culture and Heritage are a driver for social cohesion and sustainable economic growth. These three examples also show that their fabrication was contextualized in the manufacturing history of these factories, purposefully adopting the productive process in exercise. The incorporation of original drawings promoted innovation and still allowing the exhibition of the craft component in the final product.

\section{NOTES}

1 SJGS Arquitectos, Lda based in Porto is an architecture office founded in 2001 by a group of 4 partners (SóniaTeles e Silva, João Paulo Fernandes, Gustavo Rebolho, Sérgio Secca) who work in projects of co-authorship since the end of 1980s 2 Rybczynski W. (1987) A Short Story of an Idea: Home. Penguin Books, p. vii

3 Idem, p.viii

4 Heidegger,M.(1971) 'Building Dwelling Thinking' [Bauen WohnenDenken,1951)inPoetry, Language, Thought, translated by Albert Hofstadter, New York: Harper Colophon Books.

5 Idem, p. 143

6 Ibidem, p.158

7 Sharr, A. (2006) Heidegger's Hut. Cambridge (Mass): MIT Press, p. 22

8 Pallasmaa J. (2011) 'Alvar Aalto's Concept of Dwelling' in Jetsonen J. and Jetsonen S. Alvar Aalto Houses. New York: Princeton Architectural Press, pp 15-16 9 Zumthor, P. (1999) Thinking Architecture. Basel: Birkhäuser, p. 85

10 Idem, p. 87

11 In the article Phenomenology for Introductory Architectural analysis Courses. The Pentagon Methodological Approach, Pombo et al. relying upon the arguments of recognised architects regarding the importance of the phenomenological approach in 
the field of architecture, discuss extensively the legacy of architectural phenomenology in the design practice and propose a five-steps method (pentagon) to add to architectural analytical exercises. See Pombo, F., Bervoets, W., De Smet, H. (2015).'Phenomenology for Introductory Architectural analysis Courses. The Pentagon Methodological Approach.' Design and Technology Education: an International Journal, 20 (2), 58-69. 12 https://www.dn.pt/opiniao/opiniao-dn/rui-frias/o-cavalheiro-dascamelias-10627222.html retrieved on 26th May 2020

13 There are in Portuguese literature several references to camellias namely by authors as Eça de Queiróz (novel A Relíquia), António Nobre (poetry), Pedro Homem de Mello (poetry), Sophia de Mello Breyner (children book O Rapaz de Bronze). 14 Sónia Teles e Silva is one of the architects of the architecture office SJGS Arquitectos, Lda in charge of the projects discussed in this article. See note 1. 15 António Carneiro is a very skilled woodcarver with a long and successful experience in this traditional activity.

16 This exhibition was open from 15 December 2017 to 28 February 2018. It was an initiative of the Municipality of Paços de Ferreira, Câmara Municipal de Paços de Ferreira (Paços de Ferreira Town Hall) Associação Empresarial de Paços de Ferreira (Entrepreneur Association of Paços de Ferreira) and Moveltex. a This zone concentrates the largest number of furniture factories from the country in a way that Paços de Ferreira is known as the furniture capital. 17 AméricoTeles (1893-1989) was the founder of Museu Marítimo de Ilhavo (Maritime Museum of Ilhavo) which is a regional museum that mirrors people's activities related to the sea, namely the cod fishing, and to the lagoon. https:// museumaritimo.cm-ilhavo.pt/pages/137. The museum displays a valuable representation of cultural heritage through permanent and temporary collections. 18 Américo Teles (2012,posthumousedition) Guia Prático dePreparaçãode Algas Marinhas. Uma Colecção do Museu Maritimo de Ilhavo. Edição do Museu Maritimo de Ilhavoe da Câmara Municipalde Ilhavowiththesuppportof Associação dos Amigos do Museu de Ílhavo. 19 The factory is Fábrica Artesanal de Tapetes Beiriz in Beiriz, Póvoa de Varzim.

20 The most famous literary work about this tree is the poem Ginkgo biloba written by Johann Wolfgang von Goethe, published in West-Östlicher Diwan (West-Eastern Diwan) in 1819 (first edition). He read the first poem's version to Marianne von Willemer on $15^{\text {th }}$ September 1815 . He saw her again on $23^{\text {rd }}$ September and visited together the inspiring tree in the garden of Heidelberg Castle. After writing the poem's last version Goethe sent it to Marianne on $27^{\text {th }}$ September 1815 including two Ginkgo leaves taken from that garden. The manuscript with the two leaves pasted onto the poem by Goethe himself is displayed in the Goethe Museum in Düsseldorf. The Ginkgo biloba leaf with its heart-shape is in many works of art symbol of love and friendship. 21 BBG-Aluminium Systems and work metal based in Zona Industrial de Esposende.

22 Algae Identification from left to right, from top to bottom:1-Chondrus crispus Stackhouse, Praia das Pedrinhas, Apúlia. Portugal, August 1971, caught and prepared by Américo Teles; 2-Dumontia sp., Praia das Pedrinhas, Apúlia. Portugal, August 1971, caught and prepared by Américo Teles; 3-Ulva sp., Praia das Pedrinhas, Apúlia. Portugal, August 1978, caught and prepared by Américo Teles; 4-Codium Stackh, Praia das Pedrinhas, Apúlia. Portugal, September 1977, caught and prepared by Américo Teles; 5-Laminaria (Brown Algae, Rhodophyta), Praia das Pedrinhas, Apúlia. Portugal, July 2003, caught and prepared by Sónia Teles e Silva; 6-Plocamium cartilagineum (Red Algae, 
Phaeophyceae), Praia das Pedrinhas, Apúlia. Portugal, July 2002, caught and prepared by Sónia Teles e Silva; 7-Gracilaria verrucosa (Hudson) Papenfuss, Praia das Pedrinhas, Apúlia. Portugal, August 1979, caught and prepared by Américo Teles; 8- Plocamium sp., Póvoa de Varzim. Portugal, August 1956, caught and prepared by Américo Teles.

Received: 2020-04-06

Revised: 2020-07-11

Accepted: 2020-07-12 